\title{
The action of corticosteroids on orthodontic tooth movement: A literature review
}

\author{
Luegya Amorim Henriques Knop ${ }^{1}$, Ricardo Lima Shintcovsk', Luciana Borges Retamoso², \\ Ana Maria Trindade Grégio², Orlando Tanaka ${ }^{3}$
}

Introduction: Tooth movement is initially characterized by an acute sterile inflammation, followed by sequential multiple reactions in the periodontal ligament in response to biomechanical forces. Pharmacological agents such as corticosteroids may affect the course of orthodontic movement. Scientific studies show antagonistic actions of these drugs on bone resorption during tooth movement. Objective: To review the literature about the effect of corticosteroids on orthodontic tooth movement. Conclusion: Patients should be questioned regarding the use of these drugs in the orthodontic practice and for those who use them, the orthodontic treatment should be differentiated, with longer intervals between visits and periodic X-rays due to the delay in bone formation observed in some scientific studies.

Keywords: Tooth movement. Inflammation mediators. Bone remodeling. Corticosteroids.

Introdução: a movimentação dentária é caracterizada, inicialmente, por uma inflamação aguda estéril, seguida por reações múltiplas sequenciais no ligamento periodontal em resposta às forças biomecânicas. Agentes farmacológicos, como os corticosteroides, podem alterar o curso da movimentação ortodôntica. Os estudos científicos demonstram ações antagonistas dessas drogas sobre a reabsorção óssea durante a movimentação dentária. Objetivo: realizar revisão de literatura sobre a ação dos corticosteroides no movimento dentário ortodôntico. Conclusão: os pacientes devem ser questionados quanto ao uso dessas drogas na clínica ortodôntica e, para aqueles que fazem uso, o tratamento ortodôntico deve ser diferenciado, com intervalos maiores entre as consultas e solicitação periódica de radiografias devido ao atraso na neoformação óssea observado em alguns estudos científicos.

Palavras-chave: Movimentação dentária. Mediadores da inflamação. Remodelação óssea. Corticosteroides. ${ }^{1}$ MSc student in Dentistry/Orthodontics - Pontifical Catholic University of Paraná
(PUCPR).

${ }^{2}$ MSc student in Dentistry/Orthodontics (PUCPR).

${ }^{3}$ Head Professor - School of Dentistry - Biological and Health Sciences Center (CCBS) - PUCPR. Postgraduate in Dentistry/Orthodontics.

\author{
How to cite this article: KKnop LAH, Shintcovsk RL, Retamoso LB, Grégio AMT, \\ Tanaka $\mathrm{O}$. The action of corticosteroids on orthodontic tooth movement: A literature \\ review. Dental Press J Orthod. 2012 Nov-Dec;17(6):20.el-5. \\ Submitted: October 23, 2008 - Revised and accepted August 20, 2012 \\ " The author reports no commercial, proprietary or financial interest in the products \\ or companies described in this article. \\ Contact address: Luegya Amorim Henriques Knop \\ Rua Brigadeiro Franco, 2515 - Apto 901 - Centro - Curitiba/PR - Brazil \\ CEP: 80250-030 - E-mail: luegya@hotmail.com
}




\section{INTRODUCTION}

The biology of orthodontic tooth movement comprises the study of cellular, biochemical and molecular phenomena occurring in the periodontal ligament and alveolar bone.

The bone remodeling that occurs in the orthodontic movement is a dynamic process requiring coordinated cellular activities between osteoblasts, osteocytes and osteoclasts, in order to maintain the mineral tissue homeostasis. All these activities are regulated by chemical mediators, of cellular and plasmatic origin. ${ }^{9}$

It has been shown that orthodontic movement can be affected by administration of pharmacological agents. ${ }^{7,21}$ Corticosteroids are immunosuppressive and anti-inflammatory agents widely used to treat pathological processes in medical and dental practice, ${ }^{11}$ in such a way that patients under orthodontic treatment may present variations in normal bone remodeling due to the use of these drugs. ${ }^{7}$

Pithon and Ruellas ${ }^{16}$ report as imperative the acquaintance about drugs mechanism by the Dental Surgeon, as well as possible interactions on orthodontic tooth movement that may occur, in order to benefit the treatment or adjust it to the effects on the stomatognathic system.

The purpose of this work was to perform a literature review about the effects of corticosteroids on orthodontic tooth movement.

\section{REVIEW AND DISCUSSION}

Before reporting the action of corticosteroids on orthodontic tooth movement, it is essential to understand the biological principles that regulate this process.

Several theories about orthodontic tooth movement have been proposed, and all of them present the bone resorption as one of the biological effects. In the first half of the twentieth century there was already concern about the action mechanism and the events triggered by the applied force on the dental crown. The pressure-tension theory was based on the vitality of the periodontal ligament, i.e., the stimulation applied to the ligament did not involve or require stimulation coming from other structures such as the alveolar bone, for instance. The collagen fibers and the vascular system were essential for the development of this phenomenon. ${ }^{3}$

The orthodontic tooth movement is characterized by a multiple biological process involving sequential reactions of the periodontal tissue in response to biomechanical forces. Two regions can be observed in the periodontal ligament, the traction zone (Fig 1A) and the compression zone(Fig 1B). New bone is deposited in the alveolar wall on the traction side when light or heavy mechanical forces are applied. On the compression side, under light force, the alveolar bone is directly resorbed by osteoclasts located in Howship's lacunae (Fig 2). ${ }^{13}$
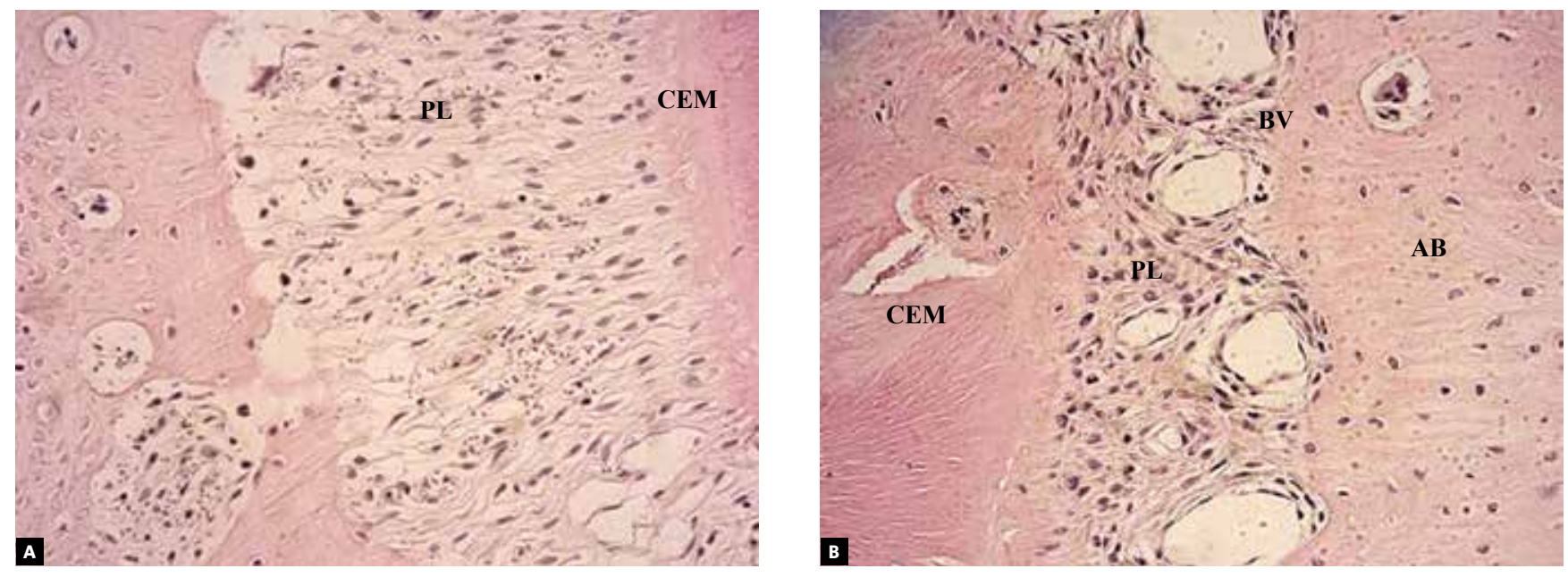

Figure 1 - A) Traction side of the periodontal ligament of mice, 3 days after application of orthodontic force (hematoxylin-eosin, 400x). B) Compression side of the periodontal ligament of mice, 3 days after application of orthodontic force (hematoxylin-eosin, 400x). $\mathrm{CEM}=$ cement; $\mathrm{PL}=$ periodontal ligament; $\mathrm{AB}=$ alveolar bone; $\mathrm{BV}=$ blood vessels. 


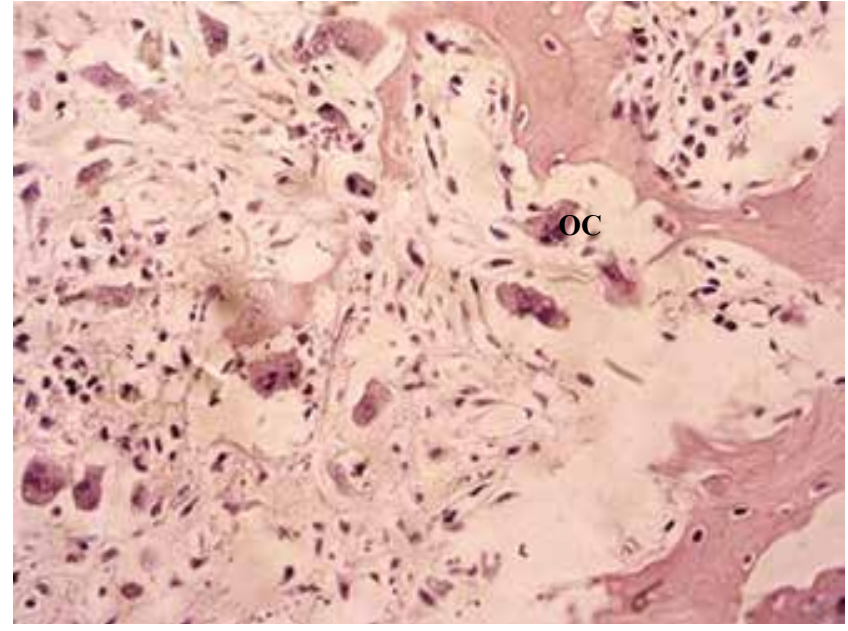

Figure 2 - Osteoclasts present in the Howship's lacunae, 7 days after application of orthodontic force in mice (hematoxylin-eosin, $x 400$ ). OC = osteoclasts.

When the force exerted on the tooth has enough strength to fully occlude the vessels and block the blood supply before the engagement of the osteoclasts, sterile necrosis is produced in the area. Due to the acellular and avascular aspect, this region is called hyaline. The tooth movement will not happen until the alveolar bone is resorbed, the hyaline areas are removed and the ligament restored. ${ }^{13}$

Inflammation comprises important prerequisite for the orthodontic tooth movement. The initial period of orthodontic tooth movement involves an acute inflammatory response, characterized by angiogenesis, periodontal vasodilation and migration of leukocytes from the blood capillaries. These cells, in turn, produce cytokines, signaling molecules that interact with resident and inflammatory cells of the periodontal ligament and stimulate the synthesis and the release of various mediators such as growth factors, prostaglandins and other cytokines. The produced inflammatory exudate, has also mediators originated from plasma, such as fibrin, plasmin, kinins, immunoglobulins and proteins of the complement system. ${ }^{9}$

The cytokines play an important role in chemotaxis, cyto-differentiation and activation of osteoclasts. ${ }^{10}$ Clinical investigations have shown that interleukin-1 $\beta$ (IL-1 $\beta$ ), tumor necrosis factor- $\alpha$ (TNF- $\alpha$ ), IL- 6 and IL-10 are in high concentration in the gingival crevicular fluid and in the periodontal ligament of orthodontic patients. IL-1 and TNF- $\alpha$ are typical inflammatory mediators involved in the bone absorption. ${ }^{2}$
According to Krishnan and Davidovitch, ${ }^{9}$ the arachidonic acid metabolites also play an important role in the process of bone remodeling during tooth movement. The Arachidonic acid is metabolized by the enzyme phospholipase $\mathrm{A}_{2}$ by two different pathways, cyclooxygenase, which produces prostaglandins and lipooxygenase, which releases leukotrienes. The prostaglandins have been associated with the increase on the number of osteoclasts and with stimulating the differentiation of osteoblasts. ${ }^{9}$

Another mediator often involved in orthodontic movement is the transforming growth factor $\beta$ (TGF- $\beta$ ), as demonstrated by Garlet et al. ${ }^{2}$ TGF- $\beta 1$ is the most abundant growth factor of human bone and plays important anabolic function by recruiting osteoblast precursors and stimulating their differentiation, besides favoring the production of bone matrix proteins and its mineralization. ${ }^{8.12}$

The vascular endothelial growth factor (VEGF) is an essential mediator for angiogenesis. Kaku et $\mathrm{al}^{6}$ observed higher concentration of VEGF in gingival crevicular fluid one day after the beginning of human canine retraction.

The biological events continue and the osteoblasts and osteoclasts are activated to initiate tissue remodeling. ${ }^{9}$

After the osteoclast differentiation, a series of enzymes such as metalloproteinases, collagenases and gelatinases, are produced by the osteoblasts. These enzymes have a major role in helping osteoclasts to access the mineralized bone tissue. ${ }^{13}$ According to Reinholt et al ${ }^{19}$ active osteoclasts show an increased content of tartrate-resistant acid phosphatase (TRAP) in the cytoplasm, an specific cytochemical marker that signalizes bone resorption.

Krishnan and Davidovitch ${ }^{9}$ report that it remains controversial whether activation of osteoblasts starts simultaneously with the recruitment of osteoclasts or in a later stage during the development of resorptive lacunae.

It has been shown that orthodontic movement can be affected by local or general administration of pharmacological agents. ${ }^{7,21}$ The prevalence of pathological processes treated by corticosteroids is widespread in the medical and dental practice, and the response from patients undergoing orthodontic treatment may differ from normal bone remodeling due to the use of these drugs. ${ }^{7}$ 
The discovery of cortisone as an effective substance in the treatment of rheumatoid arthritis initiated a new stage in the anti-inflammatory therapy. From this discovery, several synthetic and semi-synthetic derivatives products were produced as dexamethasone, prednisolone and methylprednisolone. It is known that when therapeutically administered these drugs have a powerful anti-inflammatory and immunosuppressive action.

The effect of corticosteroids cannot be attributed to a single factor. It is mentioned the reduction in the activity of neutrophils, macrophages, fibroblasts and osteoblasts; reduction in cell migration to the inflammatory site and alterations in growth factors activity such as TGF- $\beta 1$. In addition to increased synthesis of lipocortin 1 and blocking of phospholipase $A_{2}$, inhibition of gene transcription of cyclooxygenase-2 (COX-2), therefore a reduced release of prostaglandins and leucotrienos. ${ }^{10}$ Hubner et $\mathrm{al}^{5}$ demonstrated that dexamethasone inhibits the expression of proinflammatory cytokines IL- $1 \alpha$, IL- $1 \beta$ and TNF- $\alpha$, on induced skin wounds in rats.

Regarding the bone tissue, corticosteroids have several effects. For Pharoah and Heersche, ${ }^{17}$ the drug reduces in a dose-dependent way the number of multinucleate osteoclast-like cells in culture of bone marrow cells from cats, while other authors claim that corticosteroids stimulate in vitro ${ }^{4,20}$ bone resorption in time and concentration dependent way, via increased activity and/or formation of osteoclasts. ${ }^{20}$ Osteoporosis and bone resorption have been associated with secondary hyperparathyroidism induced by corticosteroids. ${ }^{7}$ Ong et al ${ }^{15}$ reported that the action of this drug may impair the formation of osteoblasts from osteoprogenitor cells and reduce collagen synthesis by mature osteoblasts.

Few studies have been conducted aiming to demonstrate possible action of corticosteroids on orthodontic tooth movement. ${ }^{1,7,14,15,20}$

Ashcraft et $a^{1}$ studying rabbits submitted to the action of hydrocortisone acetate $(15 \mathrm{mg} / \mathrm{kg})$, which was given 4 days before induction of tooth movement until euthanasia of the animals, after 14 and 21 days. The results were consistent in showing that the tooth movement was accelerated in the experimental groups (3-4 times faster) and it was histologically observed increased bone resorption and decreased bone formation. In this study, high doses of hydrocortisone were administered for a longer period, which induced rats to the condition of osteoporosis, thus increasing the bone resorption rate.

Ohkawa $^{14}$ administered hydrocortisone at a dose of $10 \mathrm{mg} / \mathrm{kg}$ in rats, induced tooth movement by means of an elastic band and evaluated the amount of mechanical stress required to extract the inferior first molars. According to the author, the load required to extract the tooth is inversely proportional to the strength of the periodontium and the remodeling of collagen fibers present in the periodontal ligament. It was observed that the mechanical stress is higher in the group that was given to hydrocortisone, and therefore the drug is able to slow down the remodeling of the collagen fibers periodontal after force application.

Yamane et $\mathrm{al}^{21}$ evaluated in vitro the tooth movement after hydrocortisone administered at a dose of $10 \mathrm{mg} / \mathrm{kg}$ /day for 7 days on rats and observed for 20 hours the amount of movement of the first and second molars using a video recorder. It was found that the group treated with corticosteroid had a lower amount of tooth movement.

Ong et $\mathrm{al}^{15}$ administered $1 \mathrm{mg} / \mathrm{kg} /$ day of prednisolone for 12 days before the induction of tooth movement in rats. There was lower amount of TRAP-positive cells on the compression side, which indicates a suppressive action of this drug on the clastic activity.

The study by Kaliaet $\mathrm{al}^{7}$ evaluated the action of the methylprednisolone $(8 \mathrm{mg} / \mathrm{kg} /$ day $)$ on tooth movement in rats when this drug was administered for short and long period. In an experimental group, methylprednisolone was injected four weeks prior to inducing movement, while the other induction occurred concomitantly with the beginning of drug administration. It was observed that the rate of tooth movement and the percentage of bone resorption were higher in the group in which the methylprednisolone was administered for a long period. In the other group there was a lower rate of tooth movement, as well as bone resorption and bone formation. The long-term administration of the drug on an experimental group was able to induce hyperparathyroidism and increase the bone resorption in animals. It is inferred that the group in which the drug is administered acutely, the effects 
of methylprednisolone was predominantly anti-inflammatory, inhibiting the cascade of events subsequent to the acute inflammation.

Therefore, when comparing scientific studies, it is noticed that corticosteroids may produce opposing effects on bone resorption in induced tooth movement in animals. These differences may be explained by variations on species of studied animals, the magnitude of force used in the experiment, and mainly the dosage, the period of administration and power of the drug. ${ }^{15}$

According to Ramos et al ${ }^{18}$ corticosteroids, when experimentally used, can modify the speed of induced tooth movement, but clinically, these changes do not reflect structural changes on the trabecular bone of the jaws since the jaw bones turnover is slower than the other bones. Furthermore, to detect the effects of these drugs on the tissues, the doses used in the studies are high and the for long periods, considering the animal's lifetime. The mouse, for instance, lives an average of 1.5 year and it is submitted to the medication for 2-3 months, the equivalent to $1 / 6$ of its average life.

\section{FINAL CONSIDERATIONS}

»It is essential that patients are questioned about the use of corticosteroids in the orthodontic practice.

» The orthodontic treatment in patients using these drugs is differentiated, and it is recommended that the intervals between visits should be longer, considering that some scientific studies have observed a delay in the process of osteogenesis,

» Concomitantly, panoramic and periapical radiographs should be routinely obtained to observe possible changes in the bone,

»New studies should elucidate which molecular mechanisms are affected by the administration of corticosteroids simultaneously to application of orthodontic forces, including human studies, since animal studies have certain limitations.

\section{REFERENCES}

1. Ashcraft MB, Southard KA, Tolley EA. The effect of corticosteroid-induced osteoporosis on orthodontic tooth movement. Am J Orthod Dentofacial Orthop. 1992;102(4):310-9.

2. Garlet TP, Coelho U, Silva JS, Garlet GP. Cytokine expression pattern in compression and tension sides of the periodontal ligament during orthodontic tooth movement in humans. Eur J Oral Sci. 2007;115(5):355-62.

3. Heller IJ, Nanda R. Effect of metabolic alteration of periodontal fibers on orthodontic tooth movement. An experimental study. Am J Orthod. 1979; 75(3):239-58

4. Hofbauer LC, Gori F, Riggs BL, Lacey DL, Dunstan CR, Spelsberg TC, et al. Stimulation of osteoprotegerin ligand and inhibition of osteoprotegerin production by glucocorticoids in human osteoblastic lineage cells: potential paracrine mechanisms of glucocorticoid-induced osteoporosis. Endocrinology. 1999:140(10):4382-9.

5. Hübner G, Brauchle M, Smola H, Madlener M, Fässler R, Werner S. Differential regulation of pro-inflammatory cytokines during wound healing in normal and glucocorticoid-treated mice. Cytokine. 1996;8(7):548-56.

6. Kaku M, Motokawa M, Tohma Y, Tsuka N, Koseki H, Sunagawa H, et al. VEGF and M-CSF levels in periodontal tissue during tooth movement. Biomed Res. 2008;29(4):181-7.

7. Kalia S, Melsen B, Verna C. Tissue reaction to orthodontic tooth movement in acute and chronic corticosteroid treatment. Orthod Craniofac Res. 2004;7(1):26-34

8. Kanaan RA, Kanaan LA. Transforming growth factor beta 1, bone connection. Med Sci Monit. 2006;12(8):RA164-9.

9. Krishnan V, Davidovitch Z. Cellular, molecular, and tissue-level reactions to orthodontic force. Am J Orthod Dentofacial Orthop. 2006;129(4):469e1-32.

10. Luo JC, Shin VY, Liu ES, So WH, Ye YN, Chang FY, et al. Non-ulcerogenic dose of dexamethasone delays gastric ulcer healing in rats. J Pharmacol Exp Ther. 2003;307(2):692-8.

11. Mancini L, Paul-Clark MJ, Rosignoli G, Hannon R, Martin JE, Macintyre I, et al. Calcitonin and prednisolone display antagonistic actions on bone and have synergistic effects in experimental arthritis. Am J Pathol. 2007;170(3):1018-27.

12. Martin TJ, Ng K. Mechanisms by which cells of the osteoblast lineage control osteoclast formation and function. J Cell Biochem. 1994;56(3):357-66.

13. Meikle MC. The tissue, cellular, and molecular regulation of orthodontic tooth movement: 100 years after Carl Sandstedt. Eur J Orthod. 2006;221(3):221-40.

14. Ohkawa S. Effects of orthodontic forces and anti-inflammatory drugs on the mechanical strength of the periodontium in the rat mandibular first molar. Am J Orthod. 1982;81(6):498-502

15. Ong CK, Walsh LJ, Harbrow D, Taverne AA, Symons AL. Orthodontic tooth movement in the prednisolone-treated rat. Angle Orthod. 2000;70(2):118-25.

16. Pithon MM, Ruellas ACO. Avaliação clínica e radiográfica da influência do fenobarbital (Gardenal ${ }^{\circledR}$ ) na movimentação ortodôntica: estudo em coelhos. Rev Dental Press Ortod Ortop. 2008;13(1):34-42.

17. Pharoah MJ, Heersche JN. Dexamethasone inhibits formation of osteoclast-like cells in bone-marrow cultures. J Dent Res. 1986;65(7):1006-9.

18. Ramos LVT, Zurquim LZ, Consolaro A. A influência de medicamentos na movimentação ortodôntica: uma análise crítica da literatura. Rev Dental Press Ortod Ortop Facial. 2005;10(1):122-30

19. Reinholt FP, Widholm SM, Ek-Rylander B, Andersson G. Ultrastructural localization of a tartrate-resistant acid ATP-ase in bone. J Bone Miner Res. 1990;5(10):1055-61.

20. Swanson C, Lorentzon M, Conaway HH, Lerner UH. Glucocorticoid regulation of osteoclast differentiation and expression of receptor activator of nuclear factorkappaB (NF-kappaB) ligand, osteoprotegerin, and receptor activator of NF-kappaB in mouse calvarial bones. Endocrinology. 2006;147(7):3613-22.

21. Yamane A, Fukui T, Chiba M. In vitro measurement of orthodontic tooth movement in rats given beta-aminopropionitrile or hydrocortisone using a time-lapse videotape recorder. Eur J Orthod. 1997;19(1):21-8. 